\title{
THE ESTABLISHMENT AND DEVELOPMENT OF LOCAL SELF-GOVERNMENT IN THE RUSSIAN FEDERATION (1991-2016)
}

\begin{abstract}
The article briefly describes organization and structure of local self-governments in the Russian Federation. It points the milestones of creating and reforming local self-governments between 1991 and 2016.
\end{abstract}

Keywords: local self-government in the Russian Federation; municipal territorial units; municipal services.

The October Revolution of 1917 resulted in the development of Soviets, the vertical power structure imposed by the Bolsheviks, while local governance implying certain autonomy to resolve local problems, did not fit into the system and was abolished. It was only in 1990 that the first law on local self-government in the Soviet Union proclaimed its restoration in cities, districts, villages and settlements. In Russia the law on local self-government was adopted in July of 1991. According to the law, local self-government was regarded as citizens' activities organisation for independent (assuming one's responsibility) resolution of locally important problems on the basis of residents' interests, their historical, national, ethnic background and other features.

Soviets, elected for five years on the alternative basis for the first time in 1990, retained the function of representative body. Administrative authorities acting as executive bodies replaced executive committees of Soviets. The post of the Head of Administrative Authority was introduced. He was to be elected by citizens for five years and exercise their power by means of undivided authority. However, after the putsch was suppressed in August 1991, the President 
began to appoint Heads of regions by his decree, thus establishing their right to appoint heads of administrative authorities in districts and towns. In October 1993 President Boris N. Yeltsin dismissed local Soviets and in 1994 elections to new representative bodies of local governance were held. In most regions they were given new names - Municipal Assemblies, Municipal and District Dumas. In was only in 1996 that heads of administrative authorities in towns and districts started to be elected.

The Russian Federation Constitution adopted on 12 December 1993, declared that 'local self-government was acknowledged and guaranteed' in the country, it was autonomous within the boundaries of its powers and was exercised in urban and rural settlements and other territories. The change in their boundaries was only accepted with regard to people's opinion, which had not been considered under Soviet power. Local self-government bodies are not incorporated into the system of regional government and their structure is determined independently by citizens. Local self-government bodies autonomously manage municipal property; form, approve and adhere to the local budget, impose local taxes and duties, act as local law enforcers, and resolve other issues of local importance. The law grants them specific governmental powers backed by material and financial resources and they are accountable to the state for their execution. Local self-government has received the right to advocacy and reimbursement of the expenses inflicted by governmental authorities decisions and the restriction of local governance powers guaranteed by the Constitution and federal law.

In 1995 the federal law on general principles of local self-government in the Russian Federation was adopted. It introduced new terms: Municipal territorial unit defined as an urban, rural settlement or several settlements united by common territory, part of the area of federally important cities (Moscow, Petersburg) which exercise local self-government within their territory possess municipal property local budget and local governance elective bodies.

Municipal service is defined as full-time professional activity in local self-government bodies to exercise their powers.

Municipal territorial unit was to comprise the land of urban and rural settlements, adjoining lands of communal use, recreational zones, lands intended for settlement development and others irrespective of property types or designated purposes. All municipal territorial unit resolved a similar range of problems, 
had executive powers and were allowed to introduce individual symbols, such as coats of arms, emblems, and other symbols.

In 2003 a new federal law on general principles of local self-government in the Russian Federation was adopted, which initiated a new stage of reforms in this sphere.

Most changes occurred in the territorial basis of local governance. Five types of municipal territorial unit were introduced: urban and rural settlements, municipal districts, city areas and intercity areas within federally important cities (Moscow and St. Petersburg). Urban and rural settlements being autonomous municipalities, also joined the territories of municipal districts. City areas existed along with districts.

If a city with a million residents and a small settlement used to solve similar problems, the 2003 law first allocated a range of problems proper to settlements, districts and city areas. Thus, a settlement's authorities cater for central heating, water supply, gas, electricity, road network and transportation within the settlement, accommodation, street lights, garbage collection, settlement's archive funds, etc. A municipal district's authorities are responsible for electricity and gas provision to settlements, roads and transportation between settlements. They are in charge of kindergartens, schools, police, environmental protection, domestic and industrial waste disposal and recycling, municipal archives maintenance, etc. City areas authorities resolve all the problems that settlements and municipal districts authorities are entrusted with.

All types of municipal territorial unit form and approve to the budget, impose local taxes and duties, own, use and manage municipal property. They are empowered to adopt the Articles of Association, the official symbols, to establish municipal enterprises and institutions, impose tariffs for their services, hold municipal elections and referendums, initiate vote in order to recall a deputy or an elected mayor, or to change the boundaries or its structure. They also adopt plans and development programs, establish mass media, and promote international and foreign economic ties.

Organisational foundations of local self-government underwent considerable changes. The minimum number of deputies to representative bodies of local governance depending on the population (elected for a term of two to five years) was specified:

- 7 deputies if the population is less than 1000 inhabitants;

- 10 deputies if the population is between 1000 and 10000 inhabitants; 
- $\quad 15$ deputies if the population is between 10000 and 30000 inhabitants;

- 20 deputies if the population is between 30000 and 100000 inhabitants;

- 25 deputies if the population is between 100000 and 500000 inhabitants;

- 35 deputies if the population is more than 500000 inhabitants.

Only $10 \%$ of deputies can be employed full-time and receive a salary and not all of them, as was confirmed by the law of 1995. The head of administration may be elected by people or municipal Duma; or be employed under contract. In this case the municipal head is the chairperson of the representative body, either selected from its members or elected by citizens.

The new law expands the ways in which people can participate in local governance. For instance, public hearings were introduced. Local governance bodies have to hold them to discuss the project of Charter of a municipal unit and its amendment, to discuss the local budget and its fulfilment report, projects and development programs of municipal education, the issue of municipal education reform, etc.

The law of 2003 regulated the process of entrusting local self-governance bodies with certain governmental powers. Since 2003 only municipal districts and city areas can be entrusted with state powers by means of issuing a special law on this matter. Federal authorities, in order to entrust municipal territorial unit with its powers, issue a federal law, while state authority of constituent member entrusting municipal territorial unit with its specific powers issues a constituent member's law. The modes to control these powers to be realised and the boundaries of interference in this area were determined for the state.

The economic basis of local governance comprises municipal property, local budget funds and proprietary rights of municipal structures.

Proper revenues of local budgets include the following:

- citizens' self-assessment assets;

- local taxes (on land and individual property) and duties revenues;

- regional and federal taxes and duties revenues transferred to local budget funds according to fixed tax rates or rules of allocations;

- municipal property revenues;

- part of revenues from municipal enterprises and part of revenues collected by means of rendering fee-paying services by local governance bodies and municipal institutions;

- fines imposed by local governance bodies; 
- gratuitous allocations from higher ranking budgets: allowances with no designated purpose that are granted in case of insufficient proper assets;

- subsidies that have an intended purpose and are granted by means of shared funding;

- charitable contributions.

Annual subventions are granted by federal authorities and constituent members in order to fulfil governmental powers.

According to data for 1 January 2015, Russia has 22923 municipal territorial unit, comprising 535 city areas, 1823 municipal districts with 20298 settlements (1644 urban and 18654 rural ones). There are 267 municipal structures on the territory of federally important cities. Since May 2014 large cities with city districts are allowed to establish municipal structures within city districts but few cities (Chelyabinsk, Samara) have used the opportunity.

The primary problem of local governance is a lack of funds with the majority of municipal structures being dependent on governmental allowances, which means their autonomy is relative.

Alevtina M. Safronova

Ural Federal University 